\title{
The High Proportion of Child Brides in Africa: Implications for The Girl Child and The Society
}

\author{
Miracle Adesina \\ University of Ibadan College of Medicine \\ Mohammed Daha \\ Bauchi State University Teaching Hospital \\ Adeola Ajobiewe \\ University of Ibadan College of Medicine \\ Ruth Ifeoluwa Oladele ( $\sim$ oladeleruth@yahoo.com ) \\ University College Hospital Ibadan https://orcid.org/0000-0001-9373-1096 \\ Isaac Olufadewa \\ University of Ibadan College of Medicine \\ Toluwase Ayorinde \\ Slum and Rural Health Initiative Research Academy
}

\section{Research}

Keywords: early marriage, child marriage, prevalence, gender inequality, health disparities, human rights violation

Posted Date: August 7th, 2020

DOI: https://doi.org/10.21203/rs.3.rs-54645/v1

License: (-) (i) This work is licensed under a Creative Commons Attribution 4.0 International License. Read Full License 


\section{Abstract}

Introduction: Early marriage exposes young brides to a lot of ills, which are not limited to emotional and mental distress, school drop-out, early widowhood, Vesico-vaginal fistula (VVF) disease, etc. This study, therefore, aims to present the proportion of young girls in Africa within age groups 15-19 and 20-24 years who are married, along with the percentage of those within age 2024 years who got married before age 15 or 18 .

Methodology: This study made use of secondary data from the United Nations Population Fund (UNFPA), 2017, on the proportion of child brides in the 29 African countries. The raw data was inputted into the Microsoft Excel 2019, analyzed and presented in sentences, percentages, and tables.

Results: Niger had the highest proportion (61\%) of girls within the age 15-19 years who were married while Namibia had the lowest (5\%). Out of 28 countries, 19 countries had less than $25 \%$ of teenage girls (15-19 years) who were married. Niger also accounted for the highest proportion (91\%) of young brides married by the age $20-24$ years, while Namibia had the lowest percentage (20\%) of brides within the age $20-24$ years.

Conclusion: African countries rank among the first twenty with a high prevalence of child marriages. This practice affects the health, economic status, quality of life of these "innocent girls" both in the present and in the future. Therefore, measures to tackle this menace as recommended by UNICEF and UNFPA and emphasized by this study needs to be put in place to change this sad narrative.

\section{Introduction}

Early marriage is defined as any form of marriage involving a boy or girl younger than the age of 18 [1]. It is more prevalent in girls, as boys enjoy greater independence and fewer restrictions [2]. The prevalence of young brides was reported to be highest in Sub-Africa ranging from $23 \%$ in Kenya and $40 \%$ in Uganda [1]. Early marriage exposes young brides into emotional and mental distress, intolerance, school drop-out, Vesico Vaginal Fistula (VVF) disease, early widowhood, frustration, among others [3]. All these do not only affect the girl child but their children, families, and society at large [4].

An estimated $60 \%$ of young mothers within age 15-24 years in Gombe, north-eastern part of Nigeria, had only primary school education. Also, the majority of them had complications before or after the delivery of their child(ren) [4]. Child brides' education is usually truncated and may reinforce gender bias [5] and also increases the risk of poverty [6]. Early marriage hinders the girls' ability to continue schooling after marriage which exposes them to several adverse sociological and health-related outcomes [7]. These include compromised sexual and reproductive health, increased risk of mental problems e.g. depression, suicidal thought among others, [8, 1], higher risk of partner violence [9], decreased social and physical mobility and decreased autonomy in decision-making within and outside of the household $[10,11]$. Child marriage also predisposes young girls to high risk of early pregnancy, maternal morbidity, and maternal death [12].

Against this background, this study aims to present the proportion of young girls in Africa within age groups 15-19 and 2024 years who are married along with the percentage of those within age 20-24 years who got married before age 15 or 18 . Furthermore, this study aims to present the impacts on these proportions of the African girl child and the society at large. This unique study not only presents the result but goes the extra mile in discussing it in line with real-life and practical issues.

\section{Methods}

This study made use of secondary data on the proportion of child brides in the 29 African countries with available data. The data was made available by the UNFPA [13]. The raw data was inputted into the Microsoft Excel 2019, analyzed and presented in sentences, percentages and tables. Furthermore, as the study also focused on presenting the result in light of the future of the girl child and the society; a comprehensive search of related and supporting studies was conducted on Google, Google Scholar, and PubMed. 


\section{Results}

Niger had the highest proportion (61\%) of girls within the age of 15-19 years who were married while Namibia had the lowest (5\%). Only two countries (Ghana and Namibia) had less than 10\% of girls aged 15-19 years who were married. A total of 19 countries had less than $25 \%$ of teenage girls (15-19 years) who were married. The top 5 countries with the highest proportion of late teenage (15-19 years) brides in decreasing order were Niger (61\%), Mali (43\%), Chad (38\%), Mozambique (37\%) and Guinea (33\%).

An estimated $91 \%$ of young girls within the age of 20-24 years in Niger were married making her the country with the highest proportion of young brides (20-24 years) among the 29 countries surveyed. However, Namibia had the lowest percentage (20\%) of brides within the age 20-24 years. Only three countries (Namibia, Gabon, and Ghana) had less than 50\% of girls within the age of 20-24 years who are married. All the 29 countries surveyed had a larger proportion of older brides (20-24 years). (Table 1). 
Percentage of girls between age groups 15-19 years and 20-24 years who are married.

\begin{tabular}{|c|c|c|}
\hline Country & $15-19$ years old & $20-24$ years old \\
\hline Benin & 14 & 61 \\
\hline Burkina Faso & 32 & 81 \\
\hline Cameroon & 24 & 62 \\
\hline Chad & 38 & 78 \\
\hline Comoros & 16 & 53 \\
\hline Congo & 19 & 53 \\
\hline Cote d'Ivoire & 21 & 56 \\
\hline Congo, the Democratic Republic of the Congo & 21 & 60 \\
\hline Ethiopia & 19 & 60 \\
\hline Gabon & 14 & 44 \\
\hline The Gambia & 24 & 58 \\
\hline Ghana & 6 & 38 \\
\hline Guinea & 33 & 68 \\
\hline Kenya & 12 & 55 \\
\hline Liberia & 14 & 53 \\
\hline Malawi & 23 & 76 \\
\hline Mali & 43 & 85 \\
\hline Mozambique & 37 & 75 \\
\hline Namibia & 5 & 20 \\
\hline Nepal & 29 & 77 \\
\hline Niger & 61 & 91 \\
\hline Nigeria & 29 & 65 \\
\hline Senegal & 24 & 60 \\
\hline Sierra Leone & 19 & 59 \\
\hline Togo & 13 & 54 \\
\hline Uganda & 20 & 67 \\
\hline Zambia & 17 & 56 \\
\hline Zimbabwe & 20 & 62 \\
\hline
\end{tabular}

The data on the percentage of young wives within the age of 20-24 years becomes clear when the data on when they got married is presented (Table 2). An estimated $38 \%$ of Chad girls within the age of 20-24 years who were married got wedded before the age of 15 . This country had the highest proportion of girls in this category. However, Namibia had the lowest percentage (2\%) in this category. Six (6) of the 29 African countries surveyed had more than $15 \%$ of young wives (20-24 years) who got married before age 15 . 
Furthermore, about $67 \%$ of wives within the age of $20-24$ years in Chad got married before age 18 making Chad the country with the highest percentage in this category. However, 7\% of wives aged 20-24 years in Namibia got married before age 18. Only 5 countries (Gabon, Ghana, Namibia, Togo, Kenya) of the 29 surveyed had less than $30 \%$ of young brides aged $20-24$ years who married before age 18. (Table 2).

Table 2

Percentage of girls within the age group of 20-24 years who were married before age 15 or 18

\begin{tabular}{|c|c|c|}
\hline Country & Married before age 15 & Married before age 18 \\
\hline Benin & 11 & 32 \\
\hline Burkina Faso & 10 & 52 \\
\hline Cameroon & 13 & 38 \\
\hline Chad & 30 & 67 \\
\hline Comoros & 10 & 32 \\
\hline Congo & 6 & 33 \\
\hline Cote d'Ivoire & 10 & 33 \\
\hline Congo, the Democratic Republic of the Congo & 10 & 37 \\
\hline Ethiopia & 16 & 41 \\
\hline Gabon & 6 & 22 \\
\hline The Gambia & 9 & 30 \\
\hline Ghana & 5 & 21 \\
\hline Guinea & 21 & 52 \\
\hline Kenya & 4 & 23 \\
\hline Liberia & 9 & 36 \\
\hline Malawi & 12 & 50 \\
\hline Mali & 23 & 60 \\
\hline Mozambique & 14 & 48 \\
\hline Namibia & 2 & 7 \\
\hline Nepal & 10 & 41 \\
\hline Niger & 28 & 76 \\
\hline Nigeria & 17 & 43 \\
\hline Senegal & 12 & 33 \\
\hline Sierra Leone & 13 & 39 \\
\hline Togo & 6 & 22 \\
\hline Uganda & 10 & 40 \\
\hline Zambia & 6 & 31 \\
\hline Zimbabwe & 4 & 32 \\
\hline
\end{tabular}

\section{Discussion}


Child marriage is defined as any legal or customary union involving a boy or girl younger than the age of 18 [1] while child marriage prevalence is the percentage of women 20-24 years old who were first married or in union before they celebrated their eighteenth birthday [14]. Despite the increasing global commitment and awareness by countries to halt the harmful practice of child marriage, it has been discovered that 15 million girls are married off before the age of 18 yearly in the developing world [8]. So, this study presented the proportion of young girls in Africa within age groups 15-19 and 20-24 years who are married along with the percentage of those within age 20-24 years who got married before age 15 or 18 . Child marriage is not isolated to any continent, region, geographical, culture, or religion. It is widespread in numerous tribes and cultures across the world with the highest prevalence in sub-Sahara Africa [8].

In five African countries (Comoros, Mozambique, Niger, Ghana, and the Congo Democratic Republic) child marriage prevalence rate ranges from 32\% in Comoros to 76\% in Niger (Table 2). An estimated 32\% of girls born between 1990 and 1994 were reportedly married before the age of 18 in Comoros which represents the least proportion of child marriages in Africa in 2017 while $10 \%$ were married before age 15 . The high rate of this harmful practice may be attributed to the country's low economy, high sexual violence, and limited educational opportunity for girls. Also, 18\% of the Comoros population lives in rural areas and lives below the international poverty line [15]. Furthermore, nearly $13.9 \%$ of adolescent girls (15-19) in Comoros have experienced some form of physical or sexual assault [16]. Also, according to the net enrolment index, only $50 \%$ of girls of primary school age are given admission into the primary school [17]. Among the enrolled female primary school pupil, only a few progress to the university, as it involves travelling overseas to France or neighboring countries.

The percentage of older brides who married before age 18 in Nigeria (43\%) is high due to the remarkably high proportion of girls who have no formal education (73\%). These girls have little to no economic resources to sustain their livelihood and therefore end up getting married to men "older than their father". Also, in some parts of Nigeria, girls are married off at young ages to enhance political and economic ties among the rich or pay back debt among the poor [18].

Mozambique, which is located in the Eastern part of Africa, has $48 \%$ of married women between ages $20-24$ who were married before age 18. This country has the highest prevalence of child marriage among the African countries in the Global Program, with the except for the Sahelian countries of Burkina Faso and Niger [19]. The major drivers of child marriage, which is one of the most serious challenges against national development in Mozambique, are initiation rites linked to puberty among ethnic groups in northern and central regions [19,20] and deteriorating economic situation due to flooding and other natural disasters [21]. This result is similar to the prevalence reported in Somalia (45\%) due to the high rate of female genital mutilation, low investment in girl-child education, etc [22]. It was also observed that Bangladesh about $59 \%$ of wives between 20 and 24 years who married before age 18 [23]. This high proportion is attributed to the pressure on the central government from the conservative religious groups, coupled with high rates of natural disasters and poverty which makes the government unable to implement plans to reduce child marriage $[19,24]$.

Niger has the highest prevalence of child marriage in Africa among the countries surveyed. An estimated $76 \%$ of married women aged 20-24 were married off before the age of 18 . This high proportion may be attributed to various factors such as low autonomy and decision-making power for females about their reproductive rights, low literacy rates among females, poverty, political instability, high fertility rates, and environmental crises along with other development challenges facing the country [19]. The only country with a close value is Chad which had $67 \%$ of married women aged 20-24 who were married off before the age of 18. This relatively high rate is contributed by the rampant practice of giving out the young in marriage to reduce the parental cost of raising them; this further increases the fertility rate of the country (25).

Ghana recorded a relatively lower proportion of child brides as $21 \%$ of married women between ages $20-24$ got married before age 18. According to UNFPA-UNICEF [21], this is the lowest prevalence of all the African countries included in the global programme against early marriage. However, there exists a strong disparity between the southern, where there is the low prevalence and northern Ghana, where the prevalence is higher. Also, the International Centre for Research on Women (ICWR) study on child marriage in Ghana revealed that there are two different types of child marriage. Type I Child Marriage is characterized by strong social norms and limitations on the autonomy or freedom of adolescent girls; it is common in the northern and Sahelian regions of the country. Type II Child Marriage is common in the southern coastal part of Ghana where adolescent girls have the freedom to choose and make the decision about their sexual and reproductive rights [19]. Other African 
countries with a lower prevalence of child marriage are Gabon (22\%) and Kenya (23\%) proportion. This similarity may be due to the governments' willingness to partner with the National Action Plan (NAP) of the United Nations International Children Educational Funds (UNICEF) to end child marriage and adolescent pregnancy.

It was reported that $37 \%$ of females of $20-24$ years were married before age 18 in the Democratic Republic of Congo (DRC). This proportion is higher in rural areas than urban ones [26]. In 2010, women between 20 and 24 years living in rural areas were 1.7 times more likely to get married before 18 than their urban counterparts [26]. Poverty, gender inequality, and harmful cultural practice in the conflict-ridden areas are the possible underlying factors. In some of the rural regions of DRC, there exists a cultural belief that girls should marry at the onset of menstruation as it indicates the start of child-rearing age. The majority of South Asian nations have the prevalence of child marriage in the same range as that of DRC who had about $40 \%$ prevalence rate [14]. This can be due to some similarities in cultural and societal beliefs and practices.

\section{Research In Context}

This section discusses the results of this study in light of the present state of child marriage, gender inequality, health disparities, human rights violation that concerns the girl child and the African society. Child marriage is a global issue but the proportion of children, mostly females, affected varies from one region to another. The current trend of this harmful practice is alarming and measures are taken by the United Nations International Children Education Funds (UNICEF), to effectively combat it. Child marriage has been pointed out to be a major violation of the fundamental human rights of girls to be free to make informed decision that affect their lives and live by the consequences or benefits from shared decision making. According to a statement made by, the Executive Director of UN Women, Michelle Bachelet M.D., [27], "No girl should be robbed of her childhood, her education and health, and her aspirations. Yet, today, millions of girls are denied their rights each year when they are married as child brides." In certain clime, the girl child is ready to be given out to a man as soon as she starts menstruating, signifying the beginning of child bearing. So, it is safe to say that a child is expected to start raise another child at a tender age of 18 years or below. A high percentage of girls in Ethiopia (25\%) and Mali (45\%) had given birth before the age of 18 compared with only $1 \%$ in Germany and $10 \%$ in the United States [28].

Early marriage exposes young girls to the risks of "too-early pregnancy", child bearing and motherhood before they are physically, psychologically and emotionally ready for these duties and responsibilities. Pregnancy suppresses the immune system, [29] thus increasing the risk of acquiring different illnesses and infections Reasons for the high maternal mortality among child brides are eclampsia, postpartum hemorrhage, HIV infection, malaria, obstructed labour, etc [30]. Other health implications of early marriage vary from sexual assault, physical violence, and mental torture among others. Girls of young age given in marriage face serious health risks of suffering sexual or domestic violence as their "husbands" may not be too patient to understand their yet developing body. The visible changes that accompany puberty misinform the men seeking the hands of these young girls in marriage. Changes like development of breast, menarche, rapid increase in height and weight, and other signs of physical development make them believe they are of "marriageable age" without considering the mental and emotional maturity of these girls. They do not fully understand the concept of marriage and almost nothing is done to prepare and equip them for sexuality, conception, and motherhood. Many girl brides who marry as children are likely to experience intimate partner violence (which affects their physical, social and mental health) compared to those who marry later. Their first sexual encounter will most likely be described as forced because of the circumstance surrounding their marriage. That first forceful encounter leaves a lasting mental scar that might negatively affect them for life, hereby affecting their future. In many regions in Africa, health facilities and services are not easily accessible to the general populace not to talk of child brides due to gender inequality.

High rate of child marriage in sub-Saharan Africa may also be attributed to the unequal quota system utilized for the admission of children to primary and secondary schools in most part of the regions [19]. Figure 1 presents the prevalence of child marriage in 111 countries. This limits the ability of the girl-child to pursue her educational ambition and hence, limiting her from a bright future. In Niger, Chad, and Burkina Faso and some other countries, the major reason for this violation of the girl-child right is a wrong perception of the unnecessary waste and cost invested in the education of their girl-child, who would eventually be married off to men and would not need their education degree for marriage. This failure to adequately prepare for the future of the girlchild through acquisition of good education impacts the economic sustenance of the girl, her children and family in both short

Page $7 / 11$ 
time and also in the long run. Lack of educational opportunity can be seen as a key factor that speeds up first sexual activity in some regions [8]. All these wrong and harmful practices, no matter the justification seal a poor and bleak future for the African girl child even from a very young age.

\section{Limitations}

This study focuses on the proportion of child marriage within the regions of Africa. Although the result will help to point the rate at which child marriages are conducted based on this staunch beliefs and norms of culture, however, it did not include the current trend of this harmful practice and/or estimated population of girls aged 15-24 years who may have been affected. These are key indicators that may guide in programmes on child marriage in Africa. Also, the estimated birthrate of young brides who have begun child bearing was not considered. This value would guide in developing proper policies and programmes for the girl-child and the gender equality space.

\section{Recommendations}

In line with the developmental framework produced by the combined efforts of the United Nations Population Fund (UNFPA) and the United Nations Children's Fund (UNICEF), strategic measures have been provided to tackle the recent trends of child marriages. The leading drivers of early marriages include poverty, weak government policy, gender bias to education, restricted access to basic health facilities, and failure of the judiciary system to enact laws to protect the rights of girls.

The conglomerate body of the African Union needs to be proactive in ensuring a comprehensive and combined approach from the advocates of girls' rights in combating the challenge of maligning girls from enjoying freedom of shared decision. The judiciary system should also ensure that all perpetrators of this wicked act are brought to book. The national governments are encouraged to reach a standpoint of developing comprehensive national strategies against child marriage, share best practices with one another, and support non-government organizations in the quest to put an end to this trend.

All strata of government must ensure that all children have access to a compulsory primary education and an incentive-filled secondary education with scholarship, grants and other awards to encourage parents to keep their female children in school. The Federal Ministries of Health should develop and implement national policies aimed at promoting adolescent reproductive health with a strong focus of getting health information and services across the nation. Furthermore, there should be improvement in child delivery and emergency obstetrics care available to the young women affected by early marriage to reduce maternal mortality rate.

\section{Conclusion}

Poverty and socio-cultural norms play central role in the damaging practice of child marriages across Africa. Girls who marry early tend to come from poor family or have low level of education. This practice affects the health (social, mental, physical, emotional), economic status, quality of life of these "innocent girls" both in the present and in the future. It also has long lasting and damaging consequences on the health, economy, security, education, etc. of the nations involved. Therefore, measures to tackle this menace as recommended by UNICEF and UNFPA and emphasized by this study needs to be put in place to change this sad narrative.

\section{Declarations}

\section{Conflict of interest}

The authors declare that they have no competing interest

\section{Funding}

This study was self-funded 


\section{Ethics approval and consent to participate}

Not applicable

\section{Consent for publication}

Not applicable

\section{Availability of data and materials}

The datasets generated and/or analyzed during the current study are available at https://www.unfpa.org/child-marriage

\section{Acknowledgement}

Not applicable

\section{Authors' contributions}

MAA conceived the main points of the study. MAA was involved in the data collection, the study design and data analysis. MGD and AJA were involved in the literature review and wrote the first and second draft of the manuscript. RIO and IIO contributed to the literature search and wrote the third draft of the manuscript. RIO and TA also wrote the final draft of the manuscript. All authors approved the final version of the manuscript.

\section{References}

1. Parsons J, Edmeades J, Kes A, Petroni S, Sexton M, Wodon Q. Economic impacts of child marriage: a review of the literature. Rev Faith Int Affairs. 2015;13:12-22.

2. Lane C, Brundage CL, Kreinin T. Why We Must Invest in Early Adolescence: Early Intervention, Lasting Impact. The Journal of Adolescent Health. 2017; 61: S10 \pm S11. https://doi.org/10.1016/j.jadohealth. 2017.07.011 PMID: 28915985

3. Bala BT. Teen pregnancy: A Global Tragedy New York: Watchtower Bible and Tract Society Inc. October 8. 2003.

4. Adedokun GN, Tochukwu HE, Adedeji 00. "Early Childhood Marriage and Early Pregnancy as a Risk to Safe Motherhood", A Report on the Regional Conference on Traditional Practices Affecting the Health of Women and Children in Africa, 19-20 Nov. ICA, 2012.

5. The United Nations Children Fund (UNICEF). Child protection information sheet: Child marriage. 2006. https://www.unicef.org/publications/files/Child_Protection_Information_Sheets.pdf Accessed 16 Feb 2020

6. Otoo-Oyortey N, Pobi, S. Early marriage and poverty: Exploring links and key policy issues. Gender \& Development. 2003; 11(2):42-51.

7. Raj A. When the mother is a child: the impact of child marriage on the health and human rights of girls. Arch Dis Child. 2010;95(11):931-5.

8. United Nation Children's Funds. Ending child marriage: progress and prospects. New York, NY. 2014. Available at: http://www.unicef.org.org/media/files/Child_Marriage_Report_7_17_LR.pdf. Accessed on 14 Feb 2020.

9. Nour NM. Child marriage: a silent health and human rights issue. Rev Obstet Gynecol. 2009;2(1):51-6.

10. Delprato M, Akyeampong K, Sabates R, Hernandez-Fernandez J. On the impact of early marriage on schooling outcomes in Sub-Saharan Africa and South West Asia. Int J Educ Dev. 2015; 44:42-55.

11. Kyari GV, Ayodele J. The socio-economic effect of early marriage in North Western Nigeria. Mediterr J Soc Sci. 2014; 5(14):582.

12. Svanemyr J, Chandra-Mouli V, Christiansen CS, Mbizvo M. Preventing child marriages: First international day of the girl child "my life, my right, end child marriage". Reproductive Health. 2012; 9:31.

13. Child marriage 2017. Accessed via https://www.unfpa.org/child-marriage on 9 Feb 2020 
14. Child marriage: Latest trends and future prospects. $2018 \mathrm{https} / /$ data.unicef.org/wp-content/uploads/2018/07/ChildMarriage-Data-Brief.pdf Accessed 9 Feb 2020

15. World Bank Website Data 2014. http://data.worldbank.org/indicator/SP.ADO.TFRT Accessed 15 Feb 2020.

16. Demographic and Health Survey. Sexual violence among adolescents in Comoros. 2012.

17. Child Marriage: latest trends and future prospects for every child. P4. Data and Analytics section, Division of data, Research and Policy, New York, USA. 2018. http://data.unicef.org Accessed 10 Feb 2020.

18. National Bureau of Statistics and UNICEF. Multiple Indicator Cluster Survey Findings Report, 2017.

19. UNFPA-UNICEF. Global programme to accelerate action to end child marriage: 2017 Annual report country profiles. 2017. https://www.unicef.org/protection/files/Global_Programme_Child_Marriage_Country_Profiles_2017\%281\%29.pdf Accessed 16 Feb 2020

20. Child Marriage and adolescent Pregnancy in Mozambique: Causes and Impacts. 2015. https://resourcecentre.savethechildren.net/node/9401/pdf/en_statistical_analysis_child_marrige_adolescent_pregnancy_awlow-res.pdf Accessed 16 Feb 2020

21. UNFPA-UNICEF. Child marriage: A mapping of programmes and partners in twelve countries in East and Southern Africa 2017. https://reliefweb.int/sites/reliefweb.int/files/resources/Child\%20marriage\%20mapping_final_digital.pdf Accessed 16 Feb, 2020

22. Girls not brides. Somalia: Child marriage around the world. 2020 https://www.girlsnotbrides.org/child-marriage/somalia/ Accessed 16 Feb 2020

23. Girls not brides. Bangladesh: Child marriage around the world. $2020 \mathrm{https} / /$ www.girlsnotbrides.org/childmarriage/bangladesh/ Accessed 16 Feb 2020

24. Human Rights Watch. Marry before your house is swept away: Child marriage in Bangladesh. 2015 https://www.hrw.org/report/2015/06/09/marry-your-house-swept-away/child-marriage-bangladesh Accessed 16 Feb 2020

25. Child Marriage in West and Central Africa: At a glance. 2020 https://www.unicef.org/wca/media/2596/file Accessed 16 Feb, 2020

26. Male C, Wodon QT. Basic Profile of Child Marriage in Democratic Republic of Congo. Health, Nutrition and population Knowledge Brief: Child marriage series. World Bank Group. Washington D.C. 2016. Available at: http://documenta,worldbank.org/curated/en/448331467831741265/Basic-profile-of-child-marriage-in-the-DemocraticRepublic-of-Congo. Accessed 15 Feb 2020.

27. United Nations Women. Child marriages: 39,000 everyday- More than 140 million girls will marry between 2011 and 2020. 2013. https://www.unwomen.org/en/news/stories/2013/3/child-marriages-39000-every-day-more-than-140-million-girls-willmarry-between-2011-and-2020 Accessed 15 Feb 2020

28. Mathur S, Greene M, Malhotra A. Too young to wed: the lives, rights and health of young married girls. Washington: International Centre for Research on Women; 2003

29. Watanabe M, Iwatani Y, Kaneda T, Hidaka Y, Mitsuda N, Morimoto Y. Changes in T, B and NK lymphocyte subsets during and after normal pregnancy. Am J Reprod Immunol. 1997;37:368-77.

30. United Nations We the Children: end-decade review of the follow-up to the World World Summit for Children. Report of the Secretary-General (A/S-27/3). New York: United Nations; 2001.

https://www.un.org/en/events/pastevents/pdfs/we_the_children.pdf Accessed 15 Feb 2020

\section{Figures}




\section{MAP 4.1 Child marriage prevalence in 111 countries}
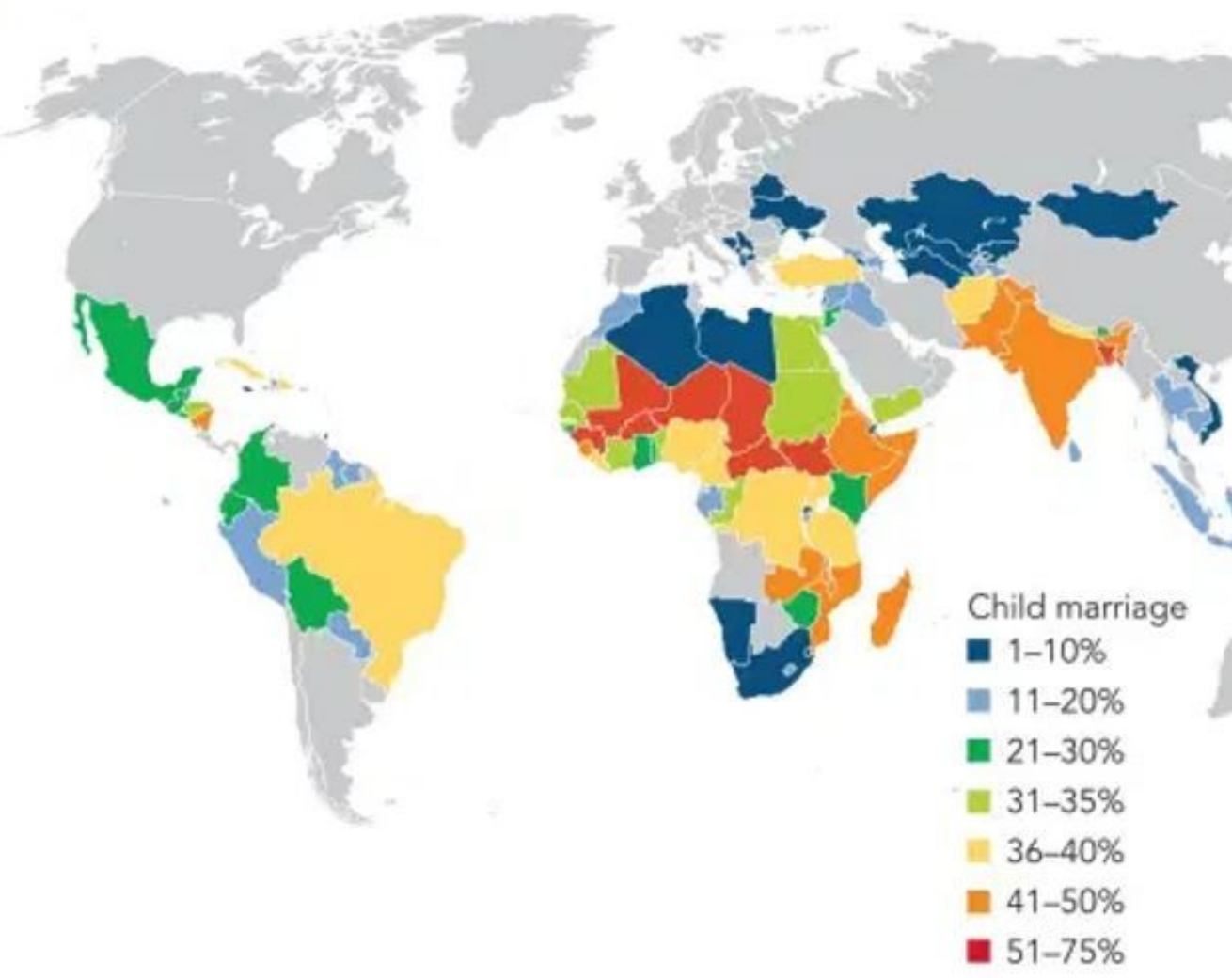

Sources: Estimates based on Demographic and Health Surveys, International Center for Research on Women reports, and United Nations Children's Fund statistics, using the latest available data for women ages 20 to 24 , 2001-12.

Note: Countries in gray do not have comparable data available.

\section{Figure 1}

Figure 1. Note: The designations employed and the presentation of the material on this map do not imply the expression of any opinion whatsoever on the part of Research Square concerning the legal status of any country, territory, city or area or of its authorities, or concerning the delimitation of its frontiers or boundaries. This map has been provided by the authors. 